\title{
Efficacy and Safety of Omadacycline Versus Linezolid in Acute Bacterial Skin and Skin Structure Infections in Persons Who Inject Drugs
}

\author{
Gregory J. Moran · Surya Chitra · Paul C. McGovern
}

Received: November 16, 2021 / Accepted: December 23, 2021 / Published online: January 11, 2022

(C) The Author(s) 2022

\begin{abstract}
Introduction: Acute bacterial skin and skin structure infections (ABSSSI) represent one of the most common reasons for emergency department visits, and are frequent complications of intravenous drug use in persons who inject drugs (PWID). This study examined the efficacy and safety of omadacycline, versus linezolid, in PWID and persons who do not inject drugs, in the Phase 3 Omadacycline in Acute Skin and Skin Structure Infection (OASIS1, OASIS-2) studies.

Methods: Eligible participants were aged $\geq 18$ years with qualifying skin infections: wound infection, cellulitis, erysipelas, or major abscess. The primary efficacy endpoint was early clinical response (ECR) in the modified intent-to-treat (mITT) population, defined as survival with $\geq 20 \%$ reduction in lesion size at $48-72 \mathrm{~h}$ after the first dose of omadacycline or linezolid. Key secondary endpoints included investigatorassessed clinical response at the post-treatment evaluation (PTE) in the mITT and clinical perprotocol populations, and clinical response at
\end{abstract}

G. J. Moran ( $\square)$

Olive View-UCLA Medical Center, 14445 Olive

View Dr, Sylmar, CA 91342, USA

e-mail: gmoran@ucla.edu

S. Chitra · P. C. McGovern

Paratek Pharmaceuticals, Inc., King of Prussia, PA, USA
PTE in the micro-mITT population. Safety was assessed based on adverse events (AEs) and standard clinical laboratory tests. Efficacy endpoints of clinical response at ECR and PTE were analyzed for the mITT and clinically evaluable (CE) PTE populations.

Results: In total, 1380 patients (822 PWID, 558 non-PWID) were included in this secondary analysis. Wound infections were reported more frequently in the PWID subgroup (72.8\%) at baseline; cellulitis or erysipelas (43.9\%) and major abscess (37.4\%) were the most frequently reported baseline infections in the non-PWID subgroup. Clinical success rates at ECR and PTE in the mITT population, and at PTE in the CE population, were high for patients receiving omadacycline or linezolid. Severe or serious treatment-emergent AEs (TEAEs), and TEAEs leading to discontinuation, were infrequent.

Conclusion: This subgroup analysis showed that omadacycline was effective and well tolerated, regardless of PWID status.

Keywords: Abscess; Cellulitis; Drug use; Erysipelas; Infectious disease; Intravenous drug use; Wounds 


\section{Key Summary Points}

Acute bacterial skin and skin structure infections (ABSSSI) are frequent complications of intravenous drug use in persons who inject drugs (PWID)

This study assessed the efficacy and safety of omadacycline versus linezolid for treatment of ABSSSI in PWID and persons who do not inject drugs in the Phase 3 OASIS- 1 and OASIS- 2 studies

Rates of clinical success were high for omadacycline and linezolid, and both drugs were well tolerated, regardless of PWID status

Although intravenous drug use can create challenges in the treatment of ABSSSI, clinical response rates were high and the drugs were well tolerated in PWID and non-PWID subgroups in this study, whether treated initially with intravenous or oral regimens

\section{INTRODUCTION}

Acute bacterial skin and skin structure infections (ABSSSI) represent one of the most common reasons for emergency department visits worldwide [1, 2]. ABSSSI include cellulitis, erysipelas, wound infections, and major cutaneous abscesses, most of which are caused by Grampositive organisms $[3,4]$. Although most ABSSSI can be treated on an outpatient basis, infections with methicillin-resistant Staphylococcus aureus (MRSA) are highly prevalent, representing about half of purulent skin infection and abscesses in the United States, and more often lead to complications and hospitalizations $[5,6]$. Between 2001 and 2009, S. aureus-related ABSSSI incidence more than doubled in the USA, from 57 to 117 infections per 100,000 people [7]. The average associated cost of an $S$. aureus-related ABSSSI hospitalization was US\$11,622 per patient, with total estimated annual costs exceeding \$4 billion [7].

Over the past two decades, increased levels of intravenous (IV) drug use in the USA have been associated with an elevated incidence of chronic viral infections, including hepatitis B and $C$, and human immunodeficiency virus [8]. Despite the increase in IV drug use, robust clinical data are limited in this population, and few recent studies have examined the incidence, microbiology, and characteristics of skin infections among persons who inject drugs (PWID) [2]. However, earlier studies suggest that ABSSSI are frequent, morbid, and costly complications of IV drug use, and are among the most common causes of hospital admissions in PWID $[6,9,10]$. In addition, the prevalence of ABSSSI in PWID may be underestimated, as many PWID are admitted for bacterial endocarditis rather than for the associated skin infection [11]. Studies performed in the USA and UK have found that almost 70\% of PWID with a current skin infection report a history of past infections [12-14].

Cultures obtained from abscesses in PWID show that, similar to the general population, most infections are likely to be caused by $S$. aureus, including MRSA [15]; however, causative pathogens may be more diverse than seen in the general population, and dependent on injection practices $[15,16]$.

A barrier to proper treatment in the PWID population is the perception by healthcare providers that PWID are more difficult to care for and have poorer outcomes in medical care than non-PWID. Perceived issues include lack of insurance coverage and non-adherence to treatment, including patient-directed discharge [17-19]. The perception that PWID are less adherent to treatment regimens may lead providers to prescribe a suboptimal therapy that is easier for the patient to follow than the preferred therapy [19]. Additionally, there is a perceived risk that IV catheters are misused by PWID at outpatient treatment centers, although this can be overcome by patient selection, tamper-proof seals, counseling, and careful monitoring of patients [17].

Omadacycline is an aminomethylcycline antibiotic, available in oral and IV formulations, 
approved in the USA for the treatment of ABSSSI and community-acquired bacterial pneumonia in adults. For the treatment of ABSSSI, omadacycline was non-inferior to linezolid in two Phase 3 studies (ClinicalTrials.gov identifiers NCT02378480, NCT02877927) [20, 21]. The post hoc secondary analysis presented here describes the PWID population from two pooled Phase 3 studies, and examines the efficacy and safety of omadacycline in PWID and in persons who do not inject drugs (non-PWID).

\section{METHODS}

\section{Study Designs}

The OASIS-1 and OASIS-2 study designs, including full inclusion and exclusion criteria, have been previously described $[20,21]$ and are briefly summarized in Table 1 . Both studies were conducted in accordance with Good Clinical Practice guidelines and provisions of the Declaration of Helsinki. The institutional review board or ethics committee at each participating site approved the protocol and amendments, and written informed consent was obtained from all participants prior to enrollment. In brief, eligible patients had one of the following qualifying skin infections, as judged by the investigator: wound infection (e.g., from IV drug use or trauma), cellulitis, erysipelas, or major abscess (capped at $\leq 30 \%$ of randomly assigned patients) that had a contiguous surface area of $\geq 75 \mathrm{~cm}^{2}$ and exhibited clear evidence of erythema, edema, or induration, as well as evidence of inflammatory response. Wound infection was defined as an infection characterized by purulent drainage from a wound with surrounding erythema, edema, and/or induration extending $\geq 5 \mathrm{~cm}$ in the shortest distance from the peripheral margin of the wound; cellulitis/ erysipelas was defined as a diffuse skin infection characterized by spreading areas of erythema, edema, and/or induration; and major abscess was defined as an infection characterized by a collection of pus within the dermis or deeper with surrounding erythema, edema, and/or induration extending $\geq 5 \mathrm{~cm}$ in the shortest distance from the peripheral margin of the abscess.

\section{Patient Population Classification and Subgroup Analyses}

The modified intent-to-treat (mITT) population included all randomized patients without a baseline sole Gram-negative ABSSSI pathogen. The micro-mITT population included all patients in the mITT population who had at

Table 1 Summary of OASIS-1 and OASIS-2 phase 3 randomized clinical trials

\begin{tabular}{|c|c|c|}
\hline Study design & $\begin{array}{l}\text { OASIS-1 (NCT02378480) } \\
\text { Double-blind, 1:1 randomization }\end{array}$ & $\begin{array}{l}\text { OASIS-2 (NCT02877927) } \\
\text { Double-blind, 1:1 randomization }\end{array}$ \\
\hline Participant age & $\geq 18$ years & $\geq 18$ years \\
\hline $\begin{array}{l}\text { Qualifying } \\
\text { infections }\end{array}$ & Wound infection, cellulitis/erysipelas, or major abscess & $\begin{array}{l}\text { Wound infection, cellulitis/erysipelas, or major } \\
\text { abscess }\end{array}$ \\
\hline \multirow[t]{3}{*}{$\begin{array}{l}\text { Treatment } \\
\text { arms }\end{array}$} & $\begin{array}{l}\text { Omadacycline: } 100 \mathrm{mg} \text { IV q12h for two doses, followed } \\
\text { by } 100 \mathrm{mg} \text { IV every } 24 \mathrm{~h} \text { q } 24 \mathrm{~h}\end{array}$ & $\begin{array}{l}\text { Omadacycline: } 450 \mathrm{mg} \text { orally once daily for } \\
\text { two doses, then } 300 \mathrm{mg} \text { orally once daily }\end{array}$ \\
\hline & Linezolid: $600 \mathrm{mg}$ IV q12h & Linezolid $600 \mathrm{mg}$ orally twice daily \\
\hline & $\begin{array}{l}\text { Option to transition to } 300 \mathrm{mg} \text { omadacycline orally } \\
\text { q24h/linezolid } 600 \mathrm{mg} \text { orally } \mathrm{q} 12 \mathrm{~h} \text { after } \geq 3 \text { days }\end{array}$ & \\
\hline Randomization & $1: 1$ & $1: 1$ \\
\hline Study duration & $7-14$ days & $7-14$ days \\
\hline
\end{tabular}


least one Gram-positive causative bacterial pathogen identified from the primary ABSSSI site. Clinically evaluable (CE) patients met protocol-specified criteria including a clinical response that was not indeterminate $[19,20]$. The safety population included all patients who received at least one dose of the study drug. Safety was assessed based on adverse events (AEs) and standard clinical laboratory tests.

The primary efficacy endpoint for both OASIS- 1 and -2 was early clinical response (ECR) in the mITT population, which defined success as survival with $\geq 20 \%$ reduction in lesion size at $48-72 \mathrm{~h}$ after the first dose of the study drug. The secondary endpoint was an investigatorassessed clinical response at the post-treatment evaluation (PTE) visit (assessed 7-14 days after the last dose of the study drug) in the mITT, CE, and micro-mITT populations. Clinical success at PTE was defined as survival with resolution of signs and symptoms of infection, such that further antibacterial therapy was not needed.

In this secondary analysis, participants in OASIS- 1 and -2 were classified as PWID or nonPWID based on whether the patient reported the primary etiology of infection was due to IV drug use. Bacterial pathogens were identified from culture samples taken from the infection site or blood specimens. Treatment compliance was calculated as $100 \times$ (number of IV doses and oral tablets actually received)/(number of IV doses and oral tablets expected).

\section{Statistical Analysis}

Efficacy endpoints of clinical response at ECR and PTE were analyzed for the mITT and CE-PTE populations. For each subgroup, the $95 \%$ confidence interval (CI) for the difference in success rates (omadacycline minus linezolid) was computed using the Miettinen-Nurminen method [22]. No formal statistical comparisons were made between PWID and non-PWID subgroups.

\section{RESULTS}

\section{Patient Demographics and Baseline Characteristics}

In total, 1380 patients received at least one dose of the study drug (safety population) and were included in this secondary analysis: 822 in the PWID subgroup and 558 in the non-PWID subgroup (Fig. 1). Approximately 98\%, 80\%, and $74 \%$ of patients qualified for the mITT, CE, and micro-mITT populations, respectively. Patient demographics and baseline characteristics of the safety population are presented in Table 2. Both PWID and non-PWID were predominately male and white. In general, the PWID population was younger, and had lower body mass index, higher rates of liver disease and elevated liver transaminases, and lower rates of chronic conditions such as diabetes and hypertension than the non-PWID population. In the non-PWID subgroup, more patients randomized to omadacycline $(28.3 \%)$ than linezolid (16.0\%) had elevated liver enzymes at baseline. In the PWID subgroup, $21.0 \%$ had a medical history of prior skin infection compared with $7.4 \%$ in the non-PWID.

\section{Baseline Infections and Pathogens in the Micro-mITT Population}

Wound infections were reported more frequently in the PWID subgroup (72.7\%) than the non-PWID (19.0\%) subgroup (Table 3). Cellulitis/erysipelas and major abscess were reported by $44.0 \%$ and $37.0 \%$ of participants in the nonPWID subgroup, and by $5.4 \%$ and $21.9 \%$ in the PWID group, respectively. Median lesion size in PWID and non-PWID was $341 \mathrm{~cm}^{2}$ (range 78-2601) and $248 \mathrm{~cm}^{2}$ (75-6739), respectively. Non-PWID presented with fever more frequently than PWID ( $29 \%$ vs. $<1 \%)$. In total, $88.7 \%(133 / 150)$ and $70.7 \%(87 / 123)$ of patients with major abscesses underwent incision and drainage in the PWID and non-PWID subgroups, respectively. In patients from whom a pathogen could be isolated, monomicrobial Gram-positive infection predominated in all infection types (Table 3). Gram-positive aerobes 


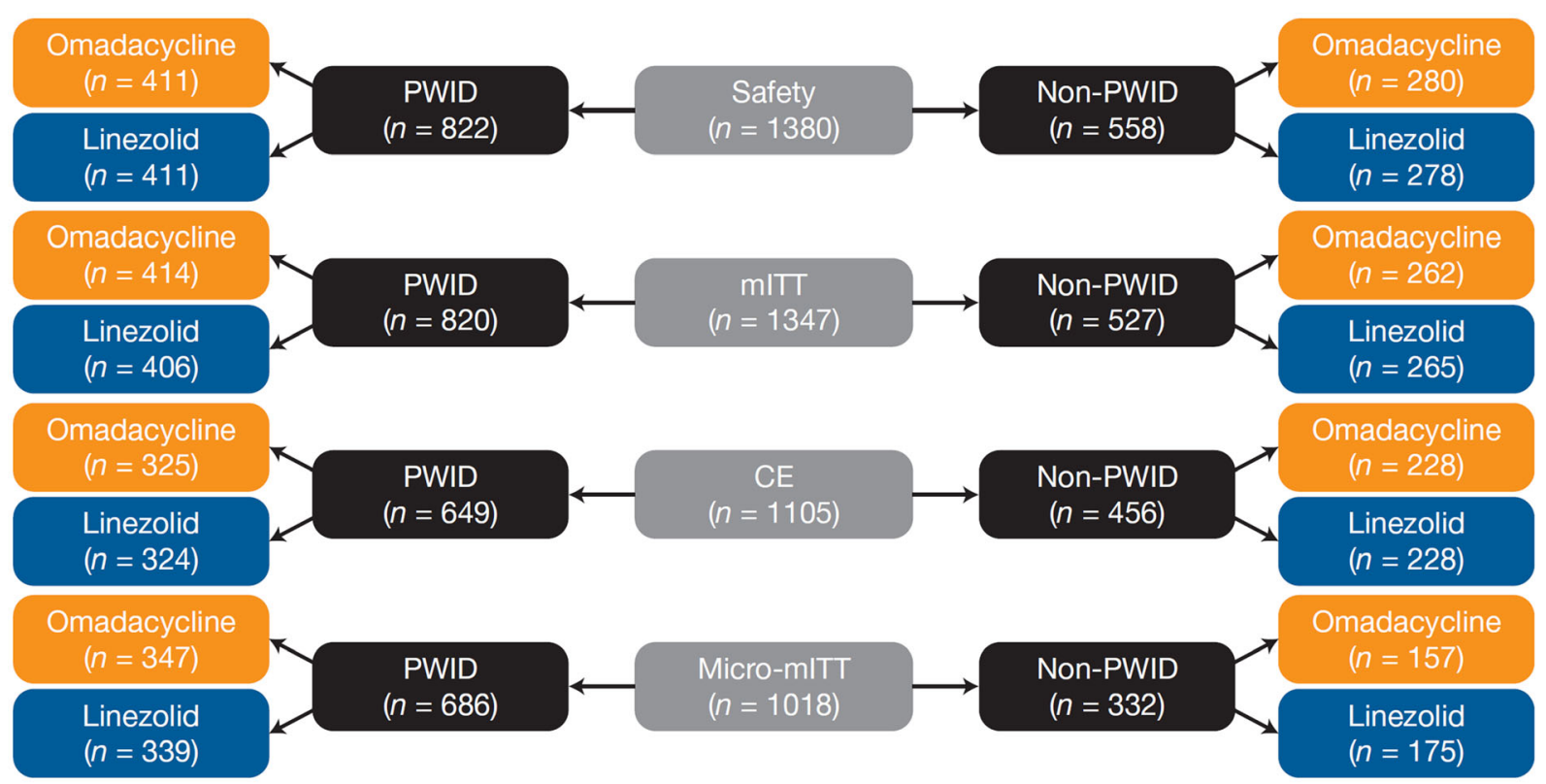

Fig. 1 Subject disposition. $C E$ clinically evaluable, mITT modified intention-to-treat, micro-mITT all mITT subjects with $\geq 1$ Gram-positive causative pathogen at baseline, PWID persons who inject drugs

were the most common pathogen types at baseline, isolated from $96.9 \%$ of all patients (Table 3). S. aureus was the most common baseline pathogen, isolated from $74 \%$ of patients in the PWID and non-PWID subgroups; methicillin-susceptible $S$. aureus (MSSA) infections occurred in greater number than MRSA infections in both groups. The Streptococcus anginosus group was identified in 25\% of PWID but only $5 \%$ of non-PWID. Group A Streptococcus ( $S$. pyogenes) was an infrequent cause of infections (4.8\% PWID; $6.6 \%$ non-PWID). Gram-positive and Gram-negative anaerobes were each identified in $\leq 10 \%$ of infections in both PWID and non-PWID in the micro-mITT population (Table 4).

\section{Patient Disposition and Study Treatment Exposure}

In total, $711 / 822(86.5 \%)$ patients in the PWID subgroup and 516/558 (92.5\%) patients in the non-PWID subgroup completed the study. In the PWID subgroup, reasons for study discontinuation (59/822 patients; $7.2 \%)$ included loss to follow-up $(44 / 822 ; 5.4 \%)$ and withdrawal by patient $(15 / 822 ; 1.8 \%)$. In the non-PWID subgroup, reasons for study discontinuation $(17 / 558 ; 3.0 \%)$ included loss to follow-up (10/ $558 ; 1.8 \%)$, withdrawal by patient $(6 / 558$; $1.1 \%)$, and physician decision $(1 / 558 ; 0.2 \%)$. Mean compliance with study drug was $98.4 \%$ in PWID and $98.8 \%$ in non-PWID, with similar rates observed in each treatment arm.

Most patients in both subgroups received treatment for 9-14 days. In the PWID subgroup, mean (standard deviation) treatment durations were 8.2 (2.7) and 8.0 (2.8) days for omadacycline and linezolid, respectively. In the nonPWID subgroup, mean (standard deviation) treatment durations were 9.3 (2.9) and 9.2 (3.0) days for omadacycline and linezolid, respectively.

\section{Clinical Efficacy (mITT and CE-PTE Populations)}

Clinical success rates exceeded $80 \%$ at ECR and PTE in the mITT population, and exceeded 90\% at PTE in the CE-PTE population for both PWID and non-PWID receiving either omadacycline or linezolid (Fig. 2). In the non-PWID subgroup, the clinical success rate at PTE was higher for omadacycline than linezolid in the mITT 
Table 2 Patient baseline demographics and characteristics (safety population)

\begin{tabular}{|c|c|c|c|c|c|c|}
\hline & \multicolumn{3}{|c|}{ PWID $(n=822)$} & \multicolumn{3}{|c|}{ Non-PWID $(n=558)$} \\
\hline & $\begin{array}{l}\text { Omadacycline } \\
(n=411)\end{array}$ & $\begin{array}{l}\text { Linezolid } \\
(n=411)\end{array}$ & $\begin{array}{l}\text { All } \\
(n=822)\end{array}$ & $\begin{array}{l}\text { Omadacycline } \\
(n=280)\end{array}$ & $\begin{array}{l}\text { Linezolid } \\
(n=278)\end{array}$ & $\begin{array}{l}\text { All } \\
(n=558)\end{array}$ \\
\hline Mean age (SD) & $41.7(11.5)$ & $42.4(11.3)$ & $42.0(11.4)$ & $49.1(16.4)$ & $50.1(16.6)$ & $49.6(16.5)$ \\
\hline \multicolumn{7}{|l|}{ Sex, $n(\%)$} \\
\hline Female & $136(33.1)$ & $140(34.1)$ & $276(33.6)$ & $110(39.3)$ & $116(41.7)$ & $226(40.5)$ \\
\hline Male & $275(66.9)$ & $271(65.9)$ & $546(66.4)$ & $170(60.7)$ & $162(58.3)$ & $332(59.5)$ \\
\hline \multicolumn{7}{|c|}{ Categorical BMI $\left(\mathrm{kg} / \mathrm{m}^{2}\right), n(\%)$} \\
\hline$n$ & 411 & 411 & 822 & 280 & 277 & 557 \\
\hline$<25$ & $178(43.3)$ & $170(41.4)$ & $348(42.3)$ & $82(29.3)$ & $75(27.1)$ & $157(28.2)$ \\
\hline $25-30$ & $137(33.3)$ & $147(35.8)$ & $284(34.5)$ & $84(30.0)$ & $96(34.7)$ & $180(32.3)$ \\
\hline$>30$ & $96(23.4)$ & $94(22.9)$ & $190(23.1)$ & $114(40.7)$ & $106(38.3)$ & $220(39.5)$ \\
\hline \multicolumn{7}{|l|}{ Race, $n(\%)$} \\
\hline White & $368(89.5)$ & $382(92.9)$ & $750(91.2)$ & $253(90.4)$ & $259(93.2)$ & $512(91.8)$ \\
\hline Non-white & $43(10.5)$ & $29(7.1)$ & $72(8.8)$ & $27(9.6)$ & $19(6.8)$ & $46(8.2)$ \\
\hline \multicolumn{7}{|l|}{ Comorbidities, $n(\%)^{\mathrm{a}}$} \\
\hline Diabetes & $4(1.0)$ & $8(1.9)$ & $12(1.5)$ & $34(12.1)$ & $59(21.2)$ & $93(16.7)$ \\
\hline Liver disease $^{\mathrm{b}}$ & $186(45.3)$ & $196(47.7)$ & $382(46.5)$ & $21(7.5)$ & $23(8.3)$ & $44(7.9)$ \\
\hline $\begin{array}{l}\text { Liver enzyme } \\
\text { elevation }\end{array}$ & $135(33.0)$ & $114(27.7)$ & $249(30.3)$ & $79(28.3)$ & $44(16.0)$ & $123(22.0)$ \\
\hline Hypertension & $50(12.2)$ & $55(13.4)$ & $105(12.8)$ & $71(25.4)$ & $85(30.6)$ & $156(28.0)$ \\
\hline $\begin{array}{l}\text { Prior skin infection, } \\
n(\%)\end{array}$ & $83(20.0)$ & $89(21.9)$ & $172(21.0)$ & $13(5.0)$ & $26(9.8)$ & $39(7.4)$ \\
\hline $\begin{array}{l}\text { Creatinine clearance, }{ }^{\mathrm{c}} \\
n(\%)\end{array}$ & 409 & 410 & 819 & 279 & 274 & 553 \\
\hline$<60 \mathrm{~mL} / \mathrm{min}$ & $2(0.5)$ & $7(1.7)$ & $9(1.1)$ & $19(6.8)$ & $14(5.1)$ & $33(6.0)$ \\
\hline $60-89 \mathrm{~mL} / \mathrm{min}$ & $29(7.1)$ & $20(4.9)$ & $49(6.0)$ & $35(12.5)$ & $31(11.3)$ & $66(11.9)$ \\
\hline$>89 \mathrm{~mL} / \mathrm{min}$ & $378(92.4)$ & $383(93.4)$ & $761(92.9)$ & $225(80.6)$ & $229(83.6)$ & $454(82.1)$ \\
\hline \multicolumn{7}{|l|}{ Lesion size, $n(\%)$} \\
\hline$\leq 300 \mathrm{~cm}^{2}$ & $164(39.9)$ & $179(43.6)$ & $343(41.7)$ & $166(59.3)$ & $163(58.6)$ & $329(59.0)$ \\
\hline$>300-600 \mathrm{~cm}^{2}$ & $154(37.5)$ & $156(38.0)$ & $310(37.7)$ & $75(26.8)$ & $68(24.5)$ & $143(25.5)$ \\
\hline$>600-1000 \mathrm{~cm}^{2}$ & $70(17.0)$ & $55(13.4)$ & $125(15.2)$ & $17(6.1)$ & $17(6.1)$ & $34(6.1)$ \\
\hline$>1000 \mathrm{~cm}^{2}$ & $23(5.6)$ & $21(5.1)$ & $44(5.4)$ & $22(7.9)$ & $30(10.8)$ & $52(9.3)$ \\
\hline \multicolumn{7}{|c|}{ Body temperature, $n(\%)$} \\
\hline$<36{ }^{\circ} \mathrm{C}$ & $4(1.0)$ & $5(1.2)$ & $9(1.1)$ & $2(0.7)$ & $2(0.7)$ & $4(0.7)$ \\
\hline
\end{tabular}


Table 2 continued

\begin{tabular}{|c|c|c|c|c|c|c|}
\hline & PWID $(n=82$ & & & Non-PWID $(n$ & 558) & \\
\hline & $\begin{array}{l}\text { Omadacycline } \\
(n=411)\end{array}$ & $\begin{array}{l}\text { Linezolid } \\
(n=411)\end{array}$ & $\begin{array}{l}\text { All } \\
(n=822)\end{array}$ & $\begin{array}{l}\text { Omadacycline } \\
(n=280)\end{array}$ & $\begin{array}{l}\text { Linezolid } \\
(n=278)\end{array}$ & $\begin{array}{l}\text { All } \\
(n=558)\end{array}$ \\
\hline 36 to $\leq 38^{\circ} \mathrm{C}$ & $403(98.1)$ & $403(98.1)$ & $806(98.1)$ & $198(70.7)$ & $193(69.4)$ & $391(70.1)$ \\
\hline$>38^{\circ} \mathrm{C}$ & $4(1.0)$ & $3(0.7)$ & $7(0.9)$ & $80(28.6)$ & $83(29.9)$ & $163(29.2)$ \\
\hline $\begin{array}{l}\text { White blood cell } \\
\text { count, } n(\%)\end{array}$ & 405 & 407 & 812 & 274 & 273 & 547 \\
\hline$\leq 4000$ cells $/ \mathrm{mm}^{3}$ & $6(1.5)$ & $2(0.5)$ & $8(1.0)$ & $2(0.7)$ & $2(0.7)$ & $4(0.7)$ \\
\hline $\begin{array}{l}>4000 \text { to }<10,000 \\
\text { cells } / \mathrm{m}^{3}\end{array}$ & $141(34.8)$ & $171(42.0)$ & $312(38.4)$ & $108(39.4)$ & $105(38.5)$ & $213(38.9)$ \\
\hline$\geq 10,000$ cells $/ \mathrm{mm}^{3}$ & $258(63.7)$ & $234(57.5)$ & $492(60.6)$ & $164(59.9)$ & $166(60.8)$ & $330(60.3)$ \\
\hline
\end{tabular}

$B M I$ body mass index, $P W I D$ persons who inject drugs, $S D$ standard deviation

${ }^{\mathrm{a}} 10$ patients $(1.1 \%)$ in the PWID group and $42(7.5 \%)$ in the non-PWID group had heart disease

${ }^{b}$ Defined as (chronic) hepatitis B, (chronic) hepatitis C, hepatic steatosis, alcoholic liver disease, hepatic cirrhosis, nonalcoholic steatohepatitis, or hepatic failure

${ }^{c}$ Calculated using the Cockcroft-Gault formula

(92.0\% vs. $85.3 \% ; 95 \%$ CI $1.3-12.3)$ and CE (97.8\% vs. $94.3 \%$; $95 \%$ CI $0.2-8.0$ ) populations. The number of indeterminates in the PWID subgroup was $13.6 \%$ in the omadacycline group and $12.6 \%$ in the linezolid group. In the nonPWID subgroup, $3.5 \%$ in the omadacycline and $6.9 \%$ in the linezolid groups were classified as indeterminate.

When assessed by individual study, clinical success rates across treatments were high in both studies. For PWID, clinical success rates at PTE were $79.1 \%$ and $81.2 \%$ in the mITT population and $94.2 \%$ and $96.7 \%$ in the CE-PTE population, in OASIS-1 and -2, respectively, whereas for non-PWID, clinical success rates at PTE were $91.0 \%$ and $85.4 \%$ in the mITT population and $95.6 \%$ and $96.7 \%$ in the CE-PTE population, in OASIS-1 and -2, respectively.

\section{Clinical Response Per Baseline Pathogen and Pathogen Mix (Micro-mITT Population)}

Clinical success rates by pathogen mix were $\geq 75 \%$ for both treatments in the PWID and non-PWID groups, with the exception of omadacycline for polymicrobial mixed infections in the PWID group (73.1\%) (Table 5). In PWID with baseline $S$. aureus infections, rates of clinical success were $86.5 \%$ and $85.9 \%$ for omadacycline and linezolid, respectively, with similar rates of clinical success in patients with baseline MRSA or MSSA infections. In nonPWID, rates of clinical success for $S$. aureus were $89.9 \%$ and $80.5 \%$ for omadacycline and linezolid, respectively; however, in patients with MRSA, clinical success rates were $90.5 \%$ and $75.4 \%$, respectively.

\section{Safety}

Rates of severe or serious treatment-emergent AEs (TEAEs), discontinuation due to TEAEs, or death were infrequent (Table 6). Nausea and vomiting were frequently reported TEAEs for both PWID and non-PWID. Patients receiving omadacycline in both the PWID and non-PWID subgroups had higher numbers of TEAEs due to greater incidence of nausea and vomiting compared with patients receiving linezolid. TEAEs of 
Table 3 Most frequently occurring baseline infection types in the subgroups (micro-mITT population)

\begin{tabular}{|c|c|c|c|c|c|c|}
\hline \multirow[t]{2}{*}{ Infection type } & \multicolumn{3}{|c|}{ PWID $(n=686)$} & \multicolumn{3}{|c|}{ Non-PWID $(n=332)$} \\
\hline & $\begin{array}{l}\text { Omadacycline } \\
(n=347) \\
n(\%)\end{array}$ & $\begin{array}{l}\text { Linezolid } \\
(n=339) \\
n(\%)\end{array}$ & $\begin{array}{l}\text { All } \\
(n=686) \\
n(\%)\end{array}$ & $\begin{array}{l}\text { Omadacycline } \\
(n=157) \\
n(\%)\end{array}$ & $\begin{array}{l}\text { Linezolid } \\
(n=175) \\
n(\%)\end{array}$ & $\begin{array}{l}\text { All } \\
(n=332) \\
n(\%)\end{array}$ \\
\hline Wound infection & $252(72.6)$ & $247(72.9)$ & $499(72.7)$ & $26(16.6)$ & $37(21.1)$ & $63(19.0)$ \\
\hline $\begin{array}{l}\text { Monomicrobial Gram- } \\
\text { positive infection }\end{array}$ & $158(62.7)$ & $178(72.1)$ & $336(67.3)$ & $14(53.8)$ & $26(70.3)$ & $40(63.5)$ \\
\hline $\begin{array}{l}\text { Polymicrobial Gram- } \\
\text { positive infection }\end{array}$ & $51(20.2)$ & $32(13.0)$ & $83(16.6)$ & $5(19.2)$ & $5(13.5)$ & $10(15.9)$ \\
\hline $\begin{array}{l}\text { Polymicrobial mixed } \\
\text { infection }\end{array}$ & $43(17.1)$ & $37(15.0)$ & $80(16.0)$ & $7(26.9)$ & $6(16.2)$ & $13(20.6)$ \\
\hline Major abscess & $72(20.7)$ & $78(23.0)$ & $150(21.9)$ & $67(42.7)$ & $56(32.0)$ & $123(37.0)$ \\
\hline $\begin{array}{l}\text { Monomicrobial Gram- } \\
\text { positive infection }\end{array}$ & $51(70.8)$ & $57(73.1)$ & $108(72.0)$ & $47(70.1)$ & $47(84.0)$ & $94(76.4)$ \\
\hline $\begin{array}{l}\text { Polymicrobial Gram- } \\
\text { positive infection }\end{array}$ & $13(18.1)$ & $16(20.5)$ & $29(19.3)$ & $11(16.4)$ & $5(8.9)$ & $16(13.0)$ \\
\hline $\begin{array}{l}\text { Polymicrobial mixed } \\
\text { infection }\end{array}$ & $8(11.1)$ & $5(6.4)$ & $13(8.7)$ & $9(13.4)$ & $4(7.1)$ & $13(10.6)$ \\
\hline Cellulitis/erysipelas & $23(6.6)$ & $14(4.1)$ & $37(5.4)$ & $64(40.8)$ & $82(46.9)$ & $146(44.0)$ \\
\hline $\begin{array}{l}\text { Monomicrobial Gram- } \\
\text { positive infection }\end{array}$ & $19(82.6)$ & $12(85.7)$ & $31(83.8)$ & $51(79.7)$ & $63(76.8)$ & $114(78.1)$ \\
\hline $\begin{array}{l}\text { Polymicrobial Gram- } \\
\text { positive infection }\end{array}$ & $3(13.0)$ & 0 & $3(8.1)$ & $8(12.5)$ & $6(7.3)$ & $14(9.6)$ \\
\hline $\begin{array}{l}\text { Polymicrobial mixed } \\
\text { infection }\end{array}$ & $1(4.3)$ & $2(14.3)$ & $3(8.1)$ & $5(7.8)$ & $13(15.9)$ & $18(12.3)$ \\
\hline
\end{tabular}

mITT modified intention-to-treat, PWID persons who inject drugs

increased liver transaminases were similar by treatment group in both PWID and non-PWID subgroups. Alanine transaminase increases postbaseline to $>3 \times$ ULN were similar for omadacycline and linezolid in PWID (5.5\% vs. $5.6 \%)$ and higher for omadacycline in non-PWID (3.6\% vs. $1.9 \%)$. No patients met the criteria for Hy's law. Skin infection TEAEs of wound infection and cellulitis were more common in PWID than non-PWID.

\section{DISCUSSION}

The results of this analysis indicate that PWID can be successfully treated with the same therapy regimens as non-PWID, despite differences in patient and disease characteristics. The PWID group included more patients with a prior ABSSSI, more wound infections at baseline, more $S$. anginosus group identification, and higher AEs of subsequent skin infections likely due to IV drug injection practices. PWID had low treatment and study discontinuation levels (i.e., adherence), suggesting that perceived behaviors associated with IV drug use did not 
Table 4 Baseline pathogen types in the subgroups (micro-mITT population)

\begin{tabular}{|c|c|c|c|c|c|c|}
\hline \multirow{2}{*}{ Pathogen type ${ }^{a}$} & \multicolumn{3}{|c|}{ PWID $(n=686)$} & \multicolumn{3}{|c|}{ Non-PWID $(n=332)$} \\
\hline & $\begin{array}{l}\text { Omadacycline } \\
(n=347) \\
n(\%)\end{array}$ & $\begin{array}{l}\text { Linezolid } \\
(n=339) \\
n(\%)\end{array}$ & $\begin{array}{l}\text { All } \\
(n=686) \\
n(\%)\end{array}$ & $\begin{array}{l}\text { Omadacycline } \\
(n=157) \\
n(\%)\end{array}$ & $\begin{array}{l}\text { Linezolid } \\
(n=175) \\
n(\%)\end{array}$ & $\begin{array}{l}\text { All } \\
(n=332) \\
n(\%)\end{array}$ \\
\hline $\begin{array}{l}\text { Gram-positive } \\
\text { aerobes }\end{array}$ & $338(97.4)$ & $328(96.8)$ & $666(97.1)$ & $152(96.8)$ & $169(96.6)$ & $321(96.7)$ \\
\hline $\begin{array}{l}\text { Staphylococcus } \\
\text { aureus }\end{array}$ & $257(74.1)$ & $256(75.5)$ & $513(74.8)$ & $119(75.8)$ & $128(73.1)$ & $247(74.4)$ \\
\hline MRSA & $110(31.7)$ & $100(29.5)$ & $210(30.6)$ & $63(40.1)$ & $57(32.6)$ & $120(36.1)$ \\
\hline MSSA & $150(43.2)$ & $160(47.2)$ & $310(45.2)$ & $58(36.9)$ & $72(41.1)$ & $130(39.2)$ \\
\hline $\begin{array}{l}\text { Streptococcus } \\
\text { pyogenes }\end{array}$ & $24(6.9)$ & $15(4.4)$ & $39(5.7)$ & $16(10.2)$ & $19(10.9)$ & $35(10.5)$ \\
\hline $\begin{array}{l}\text { Streptococcus } \\
\text { anginosus group }\end{array}$ & $96(27.7)$ & $73(21.5)$ & $169(24.6)$ & $8(5.1)$ & $9(5.1)$ & $17(5.1)$ \\
\hline $\begin{array}{l}\text { Streptococcus } \\
\text { anginosus }\end{array}$ & $31(8.9)$ & $23(6.8)$ & $54(7.9)$ & $4(2.5)$ & $4(2.3)$ & $8(2.4)$ \\
\hline $\begin{array}{l}\text { Streptococcus } \\
\text { intermedius }\end{array}$ & $32(9.2)$ & $40(11.8)$ & $72(10.5)$ & $3(1.9)$ & $2(1.1)$ & $5(1.5)$ \\
\hline $\begin{array}{l}\text { Streptococcus } \\
\text { constellatus }\end{array}$ & $33(9.5)$ & $18(5.3)$ & $51(7.4)$ & $1(0.6)$ & $3(1.7)$ & $4(1.2)$ \\
\hline Enterococcus faecalis & $3(0.9)$ & $4(1.2)$ & $7(1.0)$ & $15(9.6)$ & $21(12.0)$ & $36(10.8)$ \\
\hline $\begin{array}{c}\text { Gram-positive } \\
\text { anaerobes }\end{array}$ & $22(6.3)$ & $24(7.1)$ & $46(6.7)$ & $11(7.0)$ & $8(4.6)$ & $19(5.7)$ \\
\hline $\begin{array}{l}\text { Gram-negative } \\
\text { aerobes }\end{array}$ & $37(10.7)$ & $32(9.4)$ & $69(10.1)$ & $15(9.6)$ & $21(12.0)$ & $36(10.8)$ \\
\hline Escherichia coli & $5(1.4)$ & $0(0.0)$ & $5(0.7)$ & $1(0.6)$ & $4(2.3)$ & $5(1.5)$ \\
\hline $\begin{array}{l}\text { Klebsiella } \\
\text { pneumoniae }\end{array}$ & $9(2.6)$ & $9(2.7)$ & $18(2.6)$ & $2(1.3)$ & $2(1.1)$ & $4(1.2)$ \\
\hline $\begin{array}{c}\text { Gram-negative } \\
\text { anaerobes }^{b}\end{array}$ & $21(6.1)$ & $19(5.6)$ & $40(5.8)$ & $7(4.5)$ & $6(3.4)$ & $13(3.9)$ \\
\hline
\end{tabular}

mITT modified intention-to-treat, MRSA methicillin-resistant Staphylococcus aureus, MSSA methicillin-susceptible Staphylococcus aureus, PWID persons who inject drugs

${ }^{\text {a }}$ Patients may have had more than one pathogen at baseline

${ }^{b}$ Patients with a sole Gram-negative infection were excluded from the study, therefore patients represented in the Gramnegative rows are those with mixed infections. Includes Citrobacter koseri, Enterobacter aerogenes, Enterobacter cloacae, Escherichia coli, Escherichia vulneris, Klebsiella oxytoca, Klebsiella pneumoniae, Pantoea agglomerans, Proteus mirabilis, Raoultella planticola, and Serratia marcescens 
Omadacycline

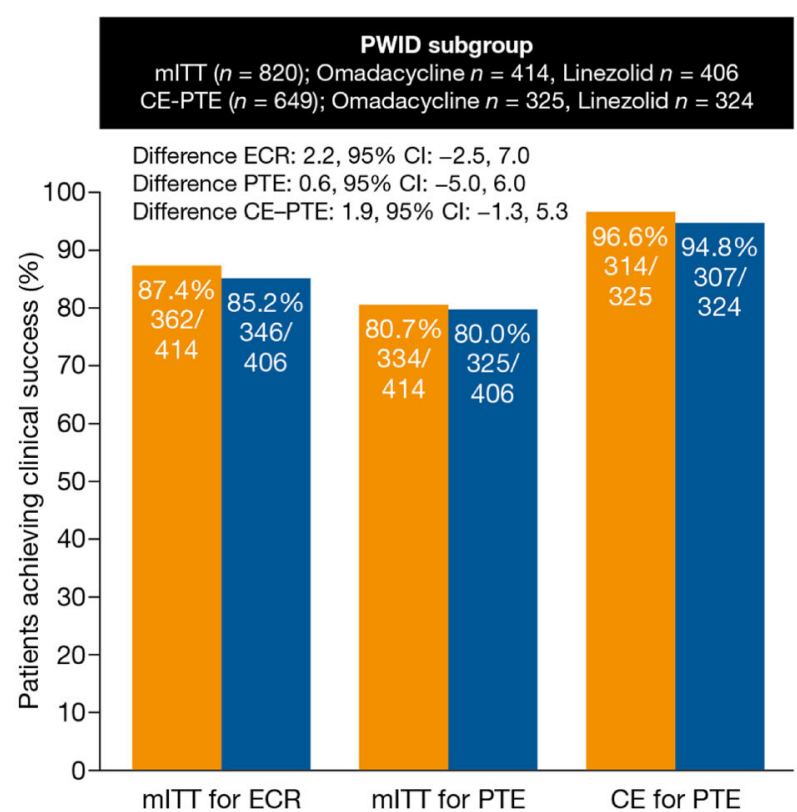

Linezolid

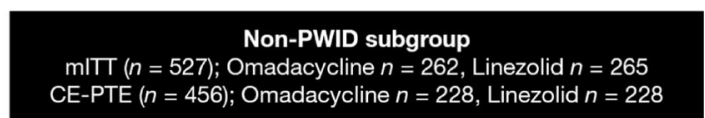

CE-PTE $(n=456)$; Omadacycline $n=228$, Linezolid $n=228$

Difference ECR: $2.5,95 \% \mathrm{Cl}:-4.0,8.9$

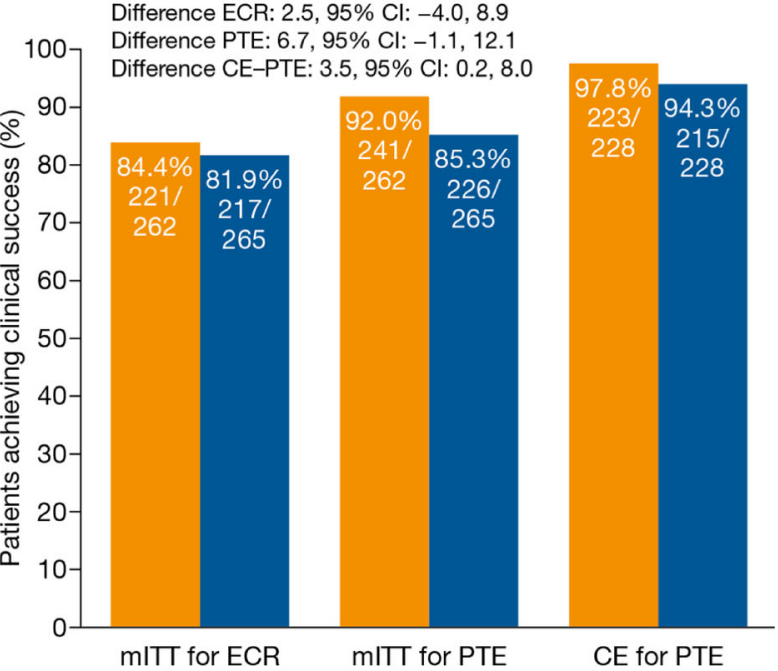

Fig. 2 Clinical success at ECR and PTE endpoints in the subgroups (mITT and CE-PTE populations). CE clinically evaluable, $C I$ confidence interval, $E C R$ early clinical response, mITT modified intention-to-treat, PTE post-treatment evaluation, $P W I D$ persons who inject drugs

Table 5 Clinical success at PTE by baseline pathogen mix (micro-mITT population)

\begin{tabular}{|c|c|c|c|c|c|c|c|c|c|c|c|c|}
\hline \multirow{3}{*}{$\begin{array}{l}\text { Baseline } \\
\text { pathogen } \\
\text { mix }\end{array}$} & \multicolumn{4}{|c|}{ PWID $(n=686)$} & \multicolumn{4}{|c|}{ Non-PWID $(n=332)$} & \multicolumn{4}{|c|}{ All patients $(n=1018)$} \\
\hline & \multicolumn{2}{|c|}{$\begin{array}{l}\text { Omadacycline } \\
(n=347)\end{array}$} & \multicolumn{2}{|c|}{$\begin{array}{l}\text { Linezolid } \\
(n=339)\end{array}$} & \multicolumn{2}{|c|}{$\begin{array}{l}\text { Omadacycline } \\
(n=157)\end{array}$} & \multicolumn{2}{|c|}{$\begin{array}{l}\text { Linezolid } \\
(n=175)\end{array}$} & \multicolumn{2}{|c|}{$\begin{array}{l}\text { PWID } \\
(n=686)\end{array}$} & \multicolumn{2}{|c|}{$\begin{array}{l}\text { Non-PWID } \\
(n=332)\end{array}$} \\
\hline & $n$ & $\begin{array}{l}\text { Clinical } \\
\text { success } \\
(n, \%)\end{array}$ & $n$ & $\begin{array}{l}\text { Clinical } \\
\text { success } \\
(n, \%)\end{array}$ & $n$ & $\begin{array}{l}\text { Clinical } \\
\text { success } \\
(n, \%)\end{array}$ & $n$ & $\begin{array}{l}\text { Clinical } \\
\text { success } \\
(n, \%)\end{array}$ & $n$ & $\begin{array}{l}\text { Clinical } \\
\text { success } \\
(n, \%)\end{array}$ & $n$ & $\begin{array}{l}\text { Clinical } \\
\text { success } \\
(n, \%)\end{array}$ \\
\hline Monomicrobial & 228 & $189(82.9)$ & 247 & $199(80.6)$ & 112 & $103(92.0)$ & 136 & $113(83.1)$ & 475 & $388(81.7)$ & 248 & $216(87.1)$ \\
\hline $\begin{array}{l}\text { Gram-positive } \\
\text { infection }\end{array}$ & & & & & & & & & & & & \\
\hline Polymicrobial & 67 & $53(79.1)$ & 48 & $36(75.0)$ & 24 & $19(79.2)$ & 16 & $12(75.0)$ & 115 & $89(77.4)$ & 40 & $31(77.5)$ \\
\hline $\begin{array}{l}\text { Gram-positive } \\
\text { infection }\end{array}$ & & & & & & & & & & & & \\
\hline Polymicrobial & 52 & $38(73.1)$ & 44 & $34(77.3)$ & 21 & $20(95.2)$ & 23 & $19(82.6)$ & 96 & $72(75.0)$ & 44 & $39(88.6)$ \\
\hline $\begin{array}{l}\text { Mixed (Gram- } \\
\text { positive and } \\
\text { Gram-negative) } \\
\text { infection }\end{array}$ & & & & & & & & & & & & \\
\hline
\end{tabular}

mITT modified intention-to-treat, $P T E$ post-treatment evaluation, $P W I D$ persons who inject drugs 
Table 6 Safety overview in the PWID and non-PWID subgroups (safety population)

\begin{tabular}{|c|c|c|c|c|}
\hline & \multicolumn{2}{|c|}{ PWID $(n=822)$} & \multicolumn{2}{|c|}{ Non-PWID $(n=558)$} \\
\hline & $\begin{array}{l}\text { Omadacycline } \\
(n=411)\end{array}$ & $\begin{array}{l}\text { Linezolid } \\
(n=411)\end{array}$ & $\begin{array}{l}\text { Omadacycline } \\
(n=280)\end{array}$ & $\begin{array}{l}\text { Linezolid } \\
(n=278)\end{array}$ \\
\hline Participants with $\geq 1$ TEAE $(n, \%)$ & $232(56.5)$ & $189(46.0)$ & $121(43.2)$ & $95(34.2)$ \\
\hline Drug-related TEAE $(n, \%)$ & $108(26.3)$ & $61(14.8)$ & $51(18.2)$ & $26(9.4)$ \\
\hline Severe $\operatorname{TEAE}(n, \%)$ & $3(0.7)$ & $4(1.0)$ & $2(0.7)$ & $7(2.5)$ \\
\hline Serious TEAE $(n, \%)$ & $5(1.2)$ & $3(0.7)$ & $0(0.0)$ & $4(1.4)$ \\
\hline Drug-related serious $\operatorname{TEAE}(n, \%)$ & $0(0.0)$ & $0(0.0)$ & $0(0.0)$ & $0(0.0)$ \\
\hline TEAE leading to discontinuation $(n, \%)$ & $5(1.2)$ & $5(1.2)$ & $3(1.1)$ & $1(0.4)$ \\
\hline Serious TEAE leading to death $(n, \%)$ & $0(0.0)$ & $1(0.2)$ & $0(0.0)$ & $2(0.7)$ \\
\hline Nausea & $108(26.3)$ & $43(10.5)$ & $43(15.4)$ & $17(6.1)$ \\
\hline Vomiting & $58(14.1)$ & $17(4.1)$ & $21(7.5)$ & $10(3.6)$ \\
\hline Wound infection & $26(6.3)$ & $21(5.1)$ & $4(1.4)$ & $1(0.4)$ \\
\hline Cellulitis & $24(5.8)$ & $18(4.4)$ & $3(1.1)$ & $6(2.2)$ \\
\hline AST increased & $19(4.6)$ & $21(5.1)$ & $6(2.1)$ & $3(1.1)$ \\
\hline ALT increased & $18(4.4)$ & $22(5.4)$ & $10(3.6)$ & $3(1.1)$ \\
\hline Headache & $12(2.9)$ & $12(2.9)$ & $11(3.9)$ & $9(3.2)$ \\
\hline Diarrhea & $11(2.7)$ & $10(2.4)$ & $11(3.9)$ & $10(3.6)$ \\
\hline
\end{tabular}

$A L T$ alanine transaminase, $A S T$ aspartate transaminase, $P W I D$ persons who inject drugs, TEAE treatment-emergent adverse event

have a substantial impact on the efficacy outcomes. Similar findings have been observed in other studies involving ABSSSI in PWID [2, 23-25], which suggest that PWID can be treated in a similar manner to non-PWID. Therefore, PWID can be transitioned to oral therapy and discharged from inpatient care following achievement of ECR (as in OASIS-1), or be treated with oral-only therapy in the community (as in OASIS-2) [20, 26, 27].

In the current studies, compliance rates were very high and similar in PWID and non-PWID. PWID may benefit from increased engagement, follow-up, and access to care, as well as preventive interventions to reduce the need for hospitalization and emergency care, and to maximize treatment adherence $[17,28]$. This could include the provision of primary care medical services for early identification of lesions and treatment of patients within the community, rather than requiring hospital admission $[29,30]$. In one study that used a "package intervention" approach to facilitate treatment of PWID in an outpatient setting, $97 \%$ of patients were compliant with the entire duration of therapy [17].

Rates of clinical success for patients receiving omadacycline and linezolid in PWID and nonPWID were both high for the ECR and PTE endpoints. Either omadacycline or oxazolidinones may be considered for ABSSSI treatment in PWID. Omadacycline's spectrum of activity, including its activity against MRSA and clinical response rates, suggests a role in the empiric treatment of PWID with any ABSSSI infection types [31]. The availability of both IV and oral formulations of omadacycline may be beneficial for treatment decisions in the emergency 
department for PWID, where patients often seek initial care. The prevalence of co-existing mental health comorbidities in PWID and in the general population [32], and widespread use of selective serotonin reuptake inhibitors, require alternatives to oxazolidinone antimicrobials in PWID and non-PWID populations.

Omadacycline was safe and well tolerated, regardless of PWID status. Nausea and vomiting were the most frequently occurring TEAEs in the subgroups, which is consistent with other studies using tetracyclines [33]. The increased rates of nausea and vomiting were generally associated with the 450-mg loading dose of omadacycline during the first 2 days of the oralonly OASIS- 2 study, which then decreased after transition to the maintenance dose [19]. The rates for nausea and vomiting were greater in the PWID subgroup, suggesting that a population characteristic (e.g., continued drug use, withdrawal) may have had an additive effect on the nausea and vomiting incidence. Liver AEs were similar by treatment group in the PWID and non-PWID subgroups, despite greater baseline and post-baseline liver transaminase elevations in the non-PWID omadacycline treatment group.

\section{Limitations}

Limitations of this subgroup analysis involving PWID are similar to those previously described for the individual OASIS- 1 and -2 studies $[20,21]$. As this was an analysis of two randomized, controlled trials, selection of patients and therefore treatment adherence, compliance, and outcomes observed within the clinical trial setting may differ from those observed in real-world situations. Additionally, this secondary post hoc analysis had no inferential testing and was not powered to determine whether true differences existed between treatment groups or between PWID and non-PWID. Baseline pathogen identification used rigorous collection methods but could have identified a non-pathogen given the site of infection. However, the high monomicrobial Gram-positive identification, in particular the high rate of $S$. aureus, is consistent with our prior understanding of the etiology of ABSSSI. Finally, it is possible that an infection could be of mixed type and potentially misclassified; however, investigators were provided with infection type definitions and were instructed to classify each infection according to its predominant type.

\section{CONCLUSIONS}

Although IV drug use can create challenges in the treatment of ABSSSI, the results of this study indicate that IV or oral omadacycline can be successfully used in PWID, with high rates of clinical success and good tolerability, and may be helpful in shortening or preventing hospitalization in PWID with ABSSSI. Additional studies are warranted to determine the optimal management and cost-effectiveness of treating ABSSSI in PWID in both inpatient and outpatient settings.

\section{ACKNOWLEDGEMENTS}

The authors thank the patients and investigators who participated in the OASIS- 1 and -2 studies, as well as Professor Charles Pollack, who presented this data at the Society for Academic Emergency Medicine conference in Las Vegas, $\mathrm{NV}$, in 2019.

Funding. This work was supported by Paratek Pharmaceuticals, Inc., in accordance with Good Publication Practice (GPP3) guidelines. The Rapid Service Fees were funded by Paratek Pharmaceuticals, Inc.

Medical writing, editorial, and other assistance. Medical writing support was provided by Megan Breuer and Jenny Engelmoer for Innovative Strategic Communications, LLC, Milford, PA, funded by Paratek Pharmaceuticals, Inc.

Authorship. All named authors meet the International Committee of Medical Journal Editors (ICMJE) criteria for authorship for this article, take responsibility for the integrity of 
the work as a whole, and have given their approval for this version to be published.

Author contributions. GJM: Acquisition of the data, analysis and interpretation of the data, critical revision of the manuscript. SC: Concept and design, acquisition of the data, analysis and interpretation of the data, statistical expertise, critical revision of the manuscript. PCM: Concept and design, acquisition of the data, analysis and interpretation of the data, critical revision of the manuscript.

Prior presentation. Society for Academic Emergency Medicine (SAEM) 2019; 16 May 2019, Las Vegas, NV, USA; Abstract 88.

Disclosures. Gregory J. Moran: Clinical trial support from I-Mab, BeiGene, ContraFect; Consulting fees and stockholder, Light AI. Surya Chitra: employee of Paratek Pharmaceuticals, Inc. Paul C. McGovern: former employee, consultant, and stockholder of Paratek Pharmaceuticals, Inc. Current affiliation: Venatorx Pharmaceuticals, Malvern, PA, USA.

Compliance with ethics guidelines. Both studies were conducted in accordance with Good Clinical Practice guidelines and provisions of the Declaration of Helsinki. The institutional review board or ethics committee at each participating site approved the protocol and amendments, and written informed consent was obtained from all participants prior to enrollment.

Data availability. Paratek Pharmaceuticals, Inc. has a commitment to ensure that access to clinical trial data is available to regulators, researchers, and trial patients, when permitted, feasible and appropriate. Requests for de-identified patient-level data may be submitted to medinfo@paratekpharma.com for review.

Open Access. This article is licensed under a Creative Commons Attribution-NonCommercial 4.0 International License, which permits any non-commercial use, sharing, adaptation, distribution and reproduction in any medium or format, as long as you give appropriate credit to the original author(s) and the source, provide a link to the Creative Commons licence, and indicate if changes were made. The images or other third party material in this article are included in the article's Creative Commons licence, unless indicated otherwise in a credit line to the material. If material is not included in the article's Creative Commons licence and your intended use is not permitted by statutory regulation or exceeds the permitted use, you will need to obtain permission directly from the copyright holder. To view a copy of this licence, visit http://creativecommons.org/licenses/by$\mathrm{nc} / 4.0 /$.

\section{REFERENCES}

1. Edelsberg J, Taneja C, Zervos M, et al. Trends in US hospital admissions for skin and soft tissue infections. Emerg Infect Dis. 2009;15:1516-8.

2. Moran GJ, De Anda C, Das AF, Green S, Mehra P, Prokocimer P. Efficacy and safety of tedizolid and linezolid for the treatment of acute bacterial skin and skin structure infections in injection drug users: analysis of two clinical trials. Infect Dis Ther. 2018;7:509-22.

3. Golan Y. Current treatment options for acute skin and skin-structure infections. Clin Infect Dis. 2019;68(Suppl 3):S206-12.

4. Pulido-Cejudo A, Guzman-Gutierrez M, JalifeMontano A, et al. Management of acute bacterial skin and skin structure infections with a focus on patients at high risk of treatment failure. Ther Adv Infect Dis. 2017;4:143-61.

5. Righi E, Carnelutti A, Vena A, Bassetti M. Emerging treatment options for acute bacterial skin and skin structure infections: focus on intravenous delafloxacin. Infect Drug Resist. 2018;11:479-88.

6. Moran GJ, Krishnadasan A, Gorwitz RJ, Fosheim GE, McDougal LK, Carey RB, Talan DA, EMERGEncy ID Net Study Group. Methicillin-resistant $S$. aureus infections among patients in the emergency department. N Engl J Med. 2006;355:666-74.

7. Suaya JA, Mera RM, Cassidy A, et al. Incidence and cost of hospitalizations associated with Staphylococcus aureus skin and soft tissue infections in the United States from 2001 through 2009. BMC Infect Dis. 2014;14:296. 
8. Kaushik KS, Kapila K, Praharaj AK. Shooting up: the interface of microbial infections and drug abuse. J Med Microbiol. 2011;60:408-22.

9. Harris RE, Richardson J, Frasso R, Anderson ED. Experiences with skin and soft tissue infections among people who inject drugs in Philadelphia: a qualitative study. Drug Alcohol Depend. 2018;187: 8-12.

10. Murphy EL, DeVita D, Liu H, et al. Risk factors for skin and soft-tissue abscesses among injection drug users: a case-control study. Clin Infect Dis. 2001;33: 35-40.

11. See I, Gokhale RH, Geller A, et al. National public health burden estimates of endocarditis and skin and soft-tissue infections related to injection drug use: a review. J Infect Dis. 2020;222(Suppl 5): S429-36.

12. Phillips KT, Stein MD. Risk practices associated with bacterial infections among injection drug users in Denver, Colorado. Am J Drug Alcohol Abuse. 2010;36:92-7.

13. Binswanger IA, Kral AH, Bluthenthal RN, Rybold DJ, Edlin BR. High prevalence of abscesses and cellulitis among community-recruited injection drug users in San Francisco. Clin Infect Dis. 2000;30: 579-81.

14. Morrison A, Elliott L, Gruer L. Injecting-related harm and treatment-seeking behaviour among injecting drug users. Addiction. 1997;92:1349-52.

15. Jenkins TC, Knepper BC, Jason Moore S, et al. Microbiology and initial antibiotic therapy for injection drug users and non-injection drug users with cutaneous abscesses in the era of communityassociated methicillin-resistant Staphylococcus aureus. Acad Emerg Med. 2015;22:993-7.

16. Summanen PH, Talan DA, Strong C, et al. Bacteriology of skin and soft-tissue infections: comparison of infections in intravenous drug users and individuals with no history of intravenous drug use. Clin Infect Dis. 1995;20(Suppl 2):S279-82.

17. Ho J, Archuleta S, Sulaiman Z, Fisher D. Safe and successful treatment of intravenous drug users with a peripherally inserted central catheter in an outpatient parenteral antibiotic treatment service. J Antimicrob Chemother. 2010;65:2641-4.

18. Jafari S, Joe R, Elliot D, Nagji A, Hayden S, Marsh DC. A community care model of intravenous antibiotic therapy for injection drug users with deep tissue infection for "Reduce leaving against medical advice." Int J Ment Health Addict. 2015;13: 49-58.
19. Mertz D, Viktorin N, Wolbers M, et al. Appropriateness of antibiotic treatment in intravenous drug users, a retrospective analysis. BMC Infect Dis. 2008;8:42.

20. O'Riordan W, Green S, Overcash JS, et al. Omadacycline for acute bacterial skin and skin-structure infections. N Engl J Med. 2019;380:528-38.

21. O'Riordan W, Cardenas C, Shin E, et al. Once daily oral omadacycline versus twice daily oral linezolid for acute bacterial skin and skin structure infections (OASIS-2): a phase 3, double-blind, multicentre, randomised, controlled, non-inferiority trial. Lancet Infect Dis. 2019;19:1080-90.

22. Miettinen O, Nurminen M. Comparative analysis of two rates. Stat Med. 1985;4:213-26.

23. Dobson PM, Loewenthal MR, Schneider K, Lai K. Comparing injecting drug users with others receiving outpatient parenteral antibiotic therapy. Open Forum Infect Dis. 2017;4:ofx183.

24. Buehrle DJ, Shields RK, Shah N, Shoff C, Sheridan K. Risk factors associated with outpatient parenteral antibiotic therapy program failure among intravenous drug users. Open Forum Infect Dis. 2017;4: ofx102.

25. Suzuki J, Johnson J, Montgomery M, Hayden M, Price C. Outpatient parenteral antimicrobial therapy among people who inject drugs: a review of the literature. Open Forum Infect Dis. 2018;5:ofy194.

26. Nathwani D, Corey R, Das AF, Sandison T, De Anda C, Prokocimer P. Early clinical response as a predictor of late treatment success in patients with acute bacterial skin and skin structure infections: retrospective analysis of 2 randomized controlled trials. Clin Infect Dis. 2017;64:214-7.

27. Shorr AF, Lodise TP, Corey GR, et al. Analysis of the phase 3 ESTABLISH trials of tedizolid versus linezolid in acute bacterial skin and skin structure infections. Antimicrob Agents Chemother. 2015;59:864-71.

28. Zeremski M, Zibbell JE, Martinez AD, Kritz S, Smith $\mathrm{BD}$, Talal AH. Hepatitis C virus control among persons who inject drugs requires overcoming barriers to care. World J Gastroenterol. 2013;19: 7846-51.

29. Takahashi TA, Merrill JO, Boyko EJ, Bradley KA. Type and location of injection drug use-related soft tissue infections predict hospitalization. J Urban Health. 2003;80:127-36.

30. Price CN, Solomon DA, Johnson JA, Montgomery MW, Martin B, Suzuki J. Feasibility and safety of outpatient parenteral antimicrobial therapy in 
conjunction with addiction treatment for people who inject drugs. J Infect Dis. 2020;222(Suppl 5): S494-8.

31. Abrahamian FM, Sakoulas G, Tzanis E, et al. Omadacycline for acute bacterial skin and skin structure infections. Clin Infect Dis. 2019;69(Suppl 1):S23-32.
32. Williams SC, Davey-Rothwell MA, Tobin KE, Latkin C. People who inject drugs and have mood disorders-a brief assessment of health risk behaviors. Subst Use Misuse. 2017;52:1181-90.

33. Heta S, Robo I. The side effects of the most commonly used group of antibiotics in periodontal treatments. Med Sci (Basel). 2018;6:6. 